\title{
BLENDED LEARNING IN ELEMENTARY CALCULUS COURSE: A CASE STUDY AT UNIVERSITAS MULTIMEDIA NUSANTARA
}

\author{
H. Meidia ${ }^{1}$, Caesar O Harahap ${ }^{2}$, Nabila Husna Shabrina ${ }^{1}$, \\ Marcel Bonar Kristanda ${ }^{3}$
}

\author{
${ }^{1}$ Department of Electrical Engineering, Faculty of Engineering and Informatics, Universitas \\ Multimedia Nusantara, Kampus UMN, JI Raya Boulevard, Gading Serpong, Tangerang 15810, \\ Indonesia \\ ${ }^{2}$ Department of Physics Engineering, Faculty of Engineering and Informatics, Universitas \\ Multimedia Nusantara, Kampus UMN, Jl Raya Boulevard, Gading Serpong, Tangerang 15810, \\ Indonesia \\ ${ }^{3}$ Department of Informatics, Faculty of Engineering and Informatics, Universitas Multimedia \\ Nusantara, Kampus UMN, JI Raya Boulevard, Gading Serpong, Tangerang 15810, Indonesia \\ E-mail : hira.meidia@umn.ac.id, nabila.husna@umn.ac.id, caesar.harahap@umn.ac.id, \\ marcel.bonar@umn.ac.id
}

\begin{abstract}
:
Although it is very important for engineering students to be competent at elementary calculus before studying core engineering subjects, the number of engineering students at Universitas Multimedia Nusantara (UMN) who fail elementary calculus course has been unacceptably high. It has been observed that the main causes of this problem are: 1. Non-repeatability of materials delivered by traditional teaching, 2. Lack of practice by doing exercise problems. To overcome these difficulties, a blended learning method was developed and implemented in an elementary calculus course in the Faculty of Engineering and Informatics at UMN. The method was a combination of traditional class teaching with online learning methods. It aimed to take the advantages of the repeatability and self-assessment facility of online learning alongside the benefits of face to face interaction in traditional teaching. The online learning materials consisted of short video captures of theoretical explanations, examples, and quizzes. They were uploaded and could be accessed through UMN's online Learning Management System (LMS). Students could watch, pause, or repeat the videos at their own pace and take quizzes which were then automatically graded. The participation log and the grades of the students until the midterm test were then monitored. Non mandatory online activities have less access by the students. Nevertheless, the percentage of students passing the midterm test was higher than the percentage in previous elementary calculus courses. Therefore, the students who studied calculus with blended learning method received an overall more effective learning experience. It also shows that the success rate of passing calculus is influenced by the motivation of the students to work on the online activities that have been prepared by the lecturer.
\end{abstract}

Keywords: Blended Learning, Calculus, Motivation, University Subject 


\section{INTRODUCTION}

The individual qualities needed by societies in education has changed with rapid development of information and communication technology (ICT). By bringing ICT as another tool in teaching and learning, it gives enormous impacts towards students. Yao Lin(2008) states that the role of technology in teaching and learning progress is important in order to increase students' motivation and achievement. E-Learning is one of the components of ICT that had been introduced in higher education to generate positive impact towards students. It is essentially a learning system that is supported by both electronic hardware and software either online (synchronous) or offline (asynchronous) [Karim \& Hashim, 2004]. One of the advantages of the e-learning is that students can choose where and when they want to learn according to their convenience. E-learning has been used to study linguistic, and it was found the students were able to do some exercise more compare with conventional teaching method. The blended learning is very favored by students in studying foreign language [Sarka Hubackova etal, 2016].

In teaching mathematics, ICT has been used to help the students to support conceptual understanding and overcome their difficulties in mathematics. Some work has been done and reported on modelling mathematical thinking in face to-face multivariable calculus classes, a review of the literature indicates that very few studies have been carried out which have been focused on the integration of strategies to invoke mathematical thinking explicitly in blended learning environment. Rohani Ahmad Tarmizi (2010) investigate students' performance in solving Calculus problems and further analysed students' difficulties in solving the problems. It was reported that some students require special treatment such as further tutorial session in correcting their misconception. Also students need to monitor their steps in problem solving or deriving problem solution.

Universitas Multimedia Nusantara (UMN) has been implementing Information and Communication Technology or ICT in its academic system to increase the effectiveness of teaching and learning process. In this paper, we report the effect of blended learning method for engineering student in studying calculus at UMN. This project was funded by SPADA Indonesia. We face problem in teaching elementary Calculus for engineering students at UMN. The number of engineering students who fail elementary calculus course has been unacceptably high. It has been observed that the main causes of this problem are the non-repeatability of materials delivered by traditional teaching and the lack of practice by doing exercise problems. Therefore, the students have difficulty understanding the lectures given in the short period of time. The lecturers need to take more lecture time to provide repetition of the material which cannot be afforded due to the short period of time in class. The lack of doing exercise of Calculus is also the problem.

Therefore, to resolve that issue, blended learning approach is considered as the right solutions to be implemented in Faculty of Engineering and Informatics, UMN. Blended learning was applied by combining the advantages of traditional in class teaching method with online learning to make the learning process more effective and efficient. The online content developed in this project were in the form of short videos and question banks as well as the solutions for student's exercises that were uploaded and the student could access through UMN's online Learning Management System (LMS). The result shows that the students studied calculus with blended learning method passed with higher passing grade compared with conventional teaching in class method. Furthermore, it also indicates that the success rate of passing calculus is influenced by the motivation of the students to work on the online activities that have been prepared by the lecturer. 


\section{LITERATURE REVIEW}

Carlos J. Asarta, James R. Schmidt (2016) compared the performance of students in blended and traditional versions of a collegiate course within the context of students' prior academic achievement. The blended version of the course used flipped and flexible instructional modes, in which only online lectures were available, class periods were used for complementary learning activities, and there was no punitive attendance policy. Significant differences in student performance between the blended and traditional versions were found within two of three zones of grade point averages. At low grade point averages, performance was higher in the traditional version of the course. At high grade point averages, performance was higher in the blended version. No significant difference was detected in the middle zone of grade point averages. The factors that lead to successful e-learning in King Saud University, Saudi Arabia, are student characteristics, instructor characteristics, ease of access, support and training [Abdullah Alhabeeb 2018]. The characteristics of student and instructor might be different from one country to another. The successful in studying with e-learning is effected by teacher selfefficacy, academic self-efficacy and computer self-efficacy [Etem Yesilyurt etal, 2016]. These attitudes toward applying computer-supported education are significantly affect online learning.

Ilona Semradova \& Sarka Hubackova reported the surveyed that they had done to the teachers at Pedagogical Faculty and the Faculty of Informatics and Management University of Hradec Kralove showed the responsibility in traditional face-to-face teaching is generally higher than in distance education. In online contexts, the emphasis is on the student as responsible for their learning process, so the self-direction for general or specific objectives, by the students, is extremely vital. The students with no self-motivation are not successful in online learning method. Rostaminezhad etal (2013) reported that there is relationship between self-regulation and e-learner dropout, the results showed that persistence e-learner had significantly high selfregulatory score than the dropout group. The ability to self-regulate learning is extremely important to overcome procrastination and achieve success factor [Maria de Fátima Goulão, Rebeca Cerezo Menedez 2015].

Mathematics is one of the key requirement for engineering students such as Calculus, Linear Algebra, etc. Hamidreza Kashefi etal (2012) show the impact of blended learning on the students' learning of multivariable calculus and in overcoming students' obstacles. The results revealed that blended learning is an adequate environment since it provides sufficient tools that support students' mathematical thinking powers to overcome their obstacles in learning multivariable calculus. Although it is clear from the protocol analyses that some students require special treatment such as further tutorial session in correcting their misconception.

To improve students learning in Calculus, there are appropriate teaching strategy. Marta Graciela Caligaris etal (2015) showed some animations of the fundamental concepts of Calculus can be used to emphasize the analysis of their geometric interpretations. There is also some strategy in the teaching the integral calculus by using some software such as GeoGebra software, Maple software, Wiris, etc. Tuan Salwani Awang etal (2013) discuss how Maple software can help to deepen the engineering technology students' understanding in integral calculus topic at the university. Rohani Ahmad Tarmizi (2010) investigated students' performance in solving Calculus problems and further analysed students' difficulties in solving the problems. Some students required special treatment such as further tutorial session in correcting their misconception. The students also needed to monitor their steps in problem solving or deriving problem solution. Much attention should be directed to fostering students ability to plan for problem solution. To solve the problem in studying calculus, the online learning is offered. M.R. Estela Carbonell etal (2012) introduces 2 techniques to teach the student in the Civil Engineering School at Universitat Politècnica de Catalunya (UPC- 
BarcelonaTech) to study Calculus. First, they used classic approach plus interactive contents: text, 2d/3d plots, labs, quizzes. Second approach was used Wiris Quizzes and motivational videos. They found that the students should find practical incentives when putting time and effort on it, and thus, they will find it easier to study Calculus. Veselin Jungic etal (2012) reported their experience creating and using online assignments for several calculus classes at Simon Fraser University (SFU). The main role of online assignments is to provide students, instructors and academic institutions with a useful, efficient and low-cost assessment and tutoring tool.

\section{METHOD}

To determine the appropriate method for this blended learning program, firstly data collection was carried out through literature study and course evaluation by the Calculus lectures. The analysis found that the solution for the problem faced by the students were described as follow.

$\square$ The material should change to be more general in the beginning of the class to make students' understanding better

$\square$ The use of E-learning would be prioritized for more effective and efficient explanation and better repetition rates for students

$\square$ Provide online quiz as a formative assessment so that students who have the special learning needs can be identified early

$\square$ Enabling online discussion so that the passive students can directly express themselves and learn to be active.

At this phase, content analysis was also carried out by instructional designers and lecturers based on the Semester Lecture Plan for academic year 2016/2017. The content analysis described the list of topics and subtopics that will be presented for students. The content analysis also determines pre-face, face-to-face and post-face-to-face learning activities and assessment methods in the form of assignments and quizzes to be combined with activities in class. The output of this activity is a Lesson Plan E-Learning document containing topics, subtopics, forms of asynchronous and synchronous learning content, material outlines covered. A sample of E-learning document can be seen in Table 1.

The development of blended learning was in the form of 7 asynchronous mode meeting before midterm exams that described as follows

$1^{\text {st }}$ meeting with a total of 17 learning videos and 1 posttest online

$2^{\text {nd }}$ meeting with a total of 24 learning videos and 1 posttest online

$3^{\text {rd }}$ meeting with a total of 11 learning videos, 1 posttest online, and 1 assignment

$4^{\text {th }}$ meeting with a total 10 learning videos

$5^{\text {th }}$ meeting with a total of 15 learning videos

$6^{\text {th }}$ meeting with a total of 15 learning videos and 1 assignment

$7^{\text {th }}$ meeting with a total of 11 learning videos

The $8^{\text {th }}$ meeting was completely online synchronous mode meeting with zoom software, pretest, and posttest online. Screenshots of samples of the learning management system, learning videos and online tests are given in Figures 1, 2, and 3, respectively. 
Table 1. Sample of Lesson Plan E-learning Document $1^{\text {st }}$ Meeting

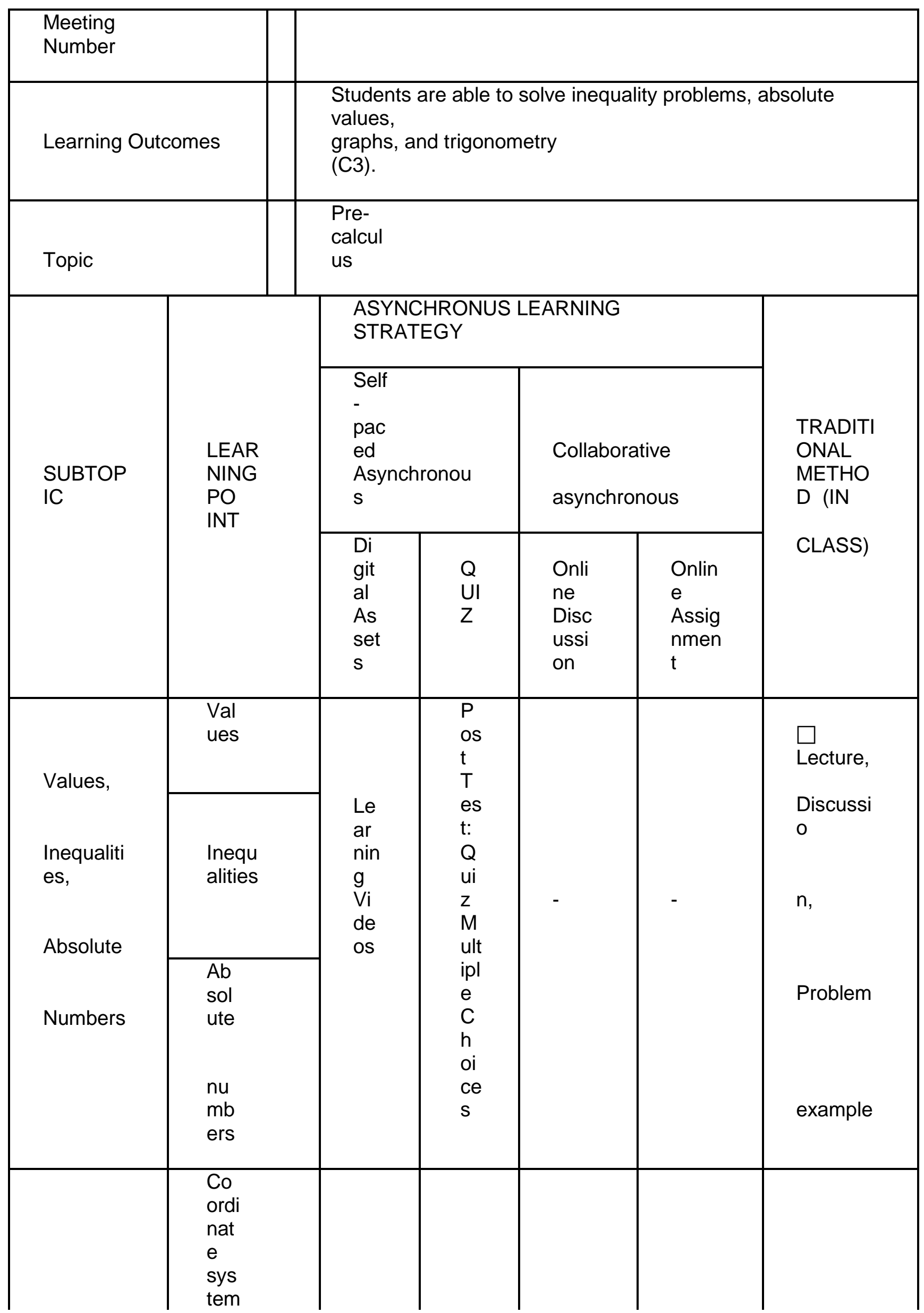




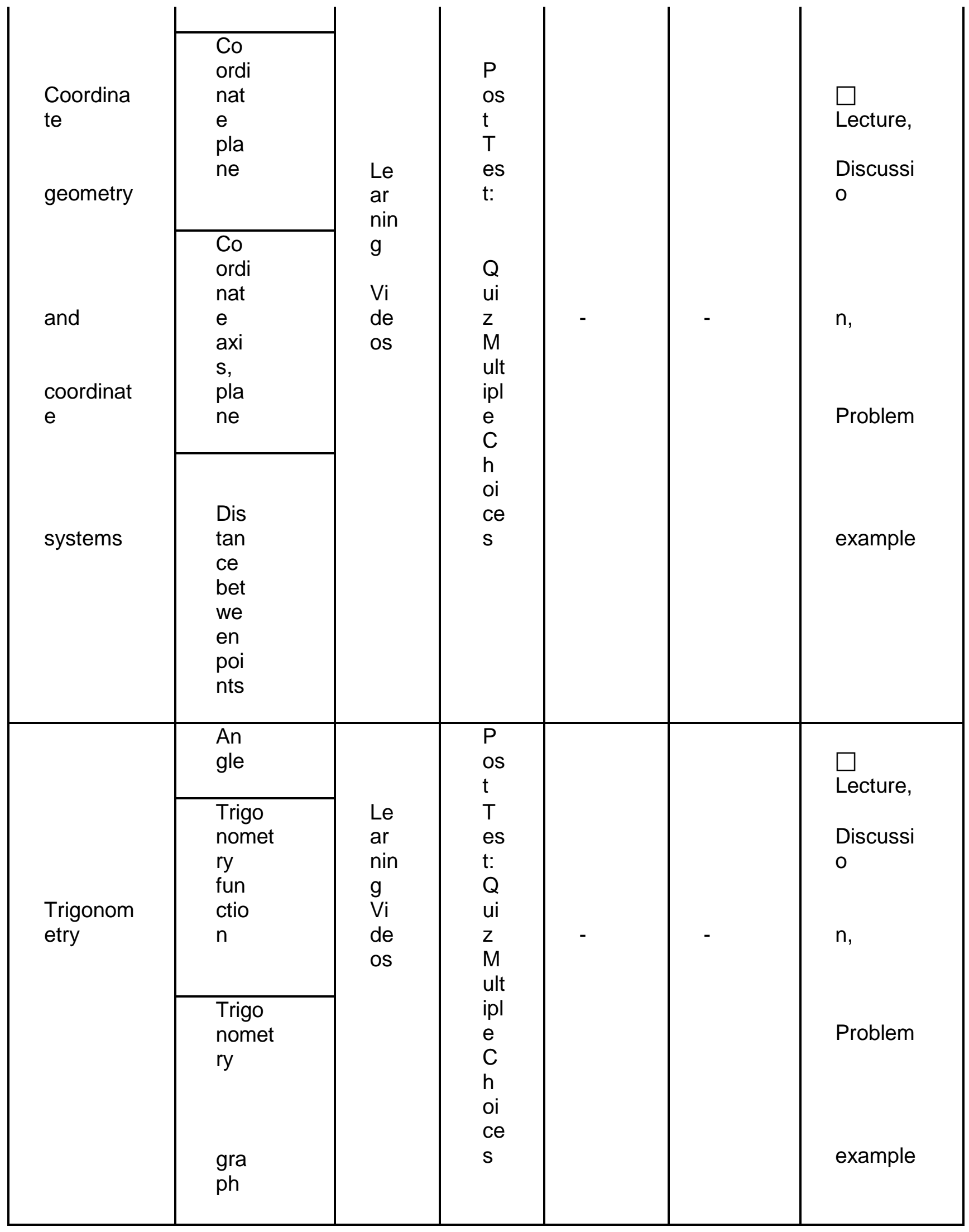


Figure 1. Screenshot of the Learning Management System

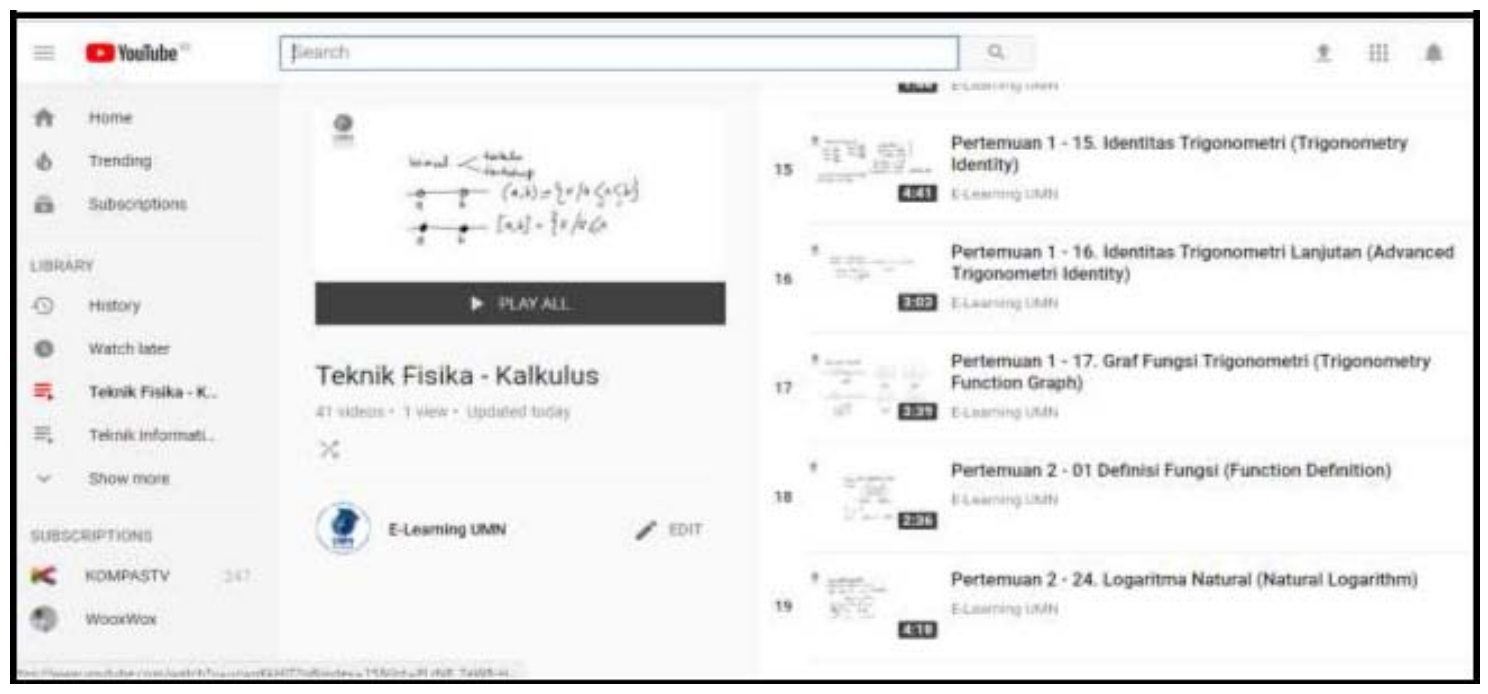

Figure 2. Screenshot of Learning Video Sample

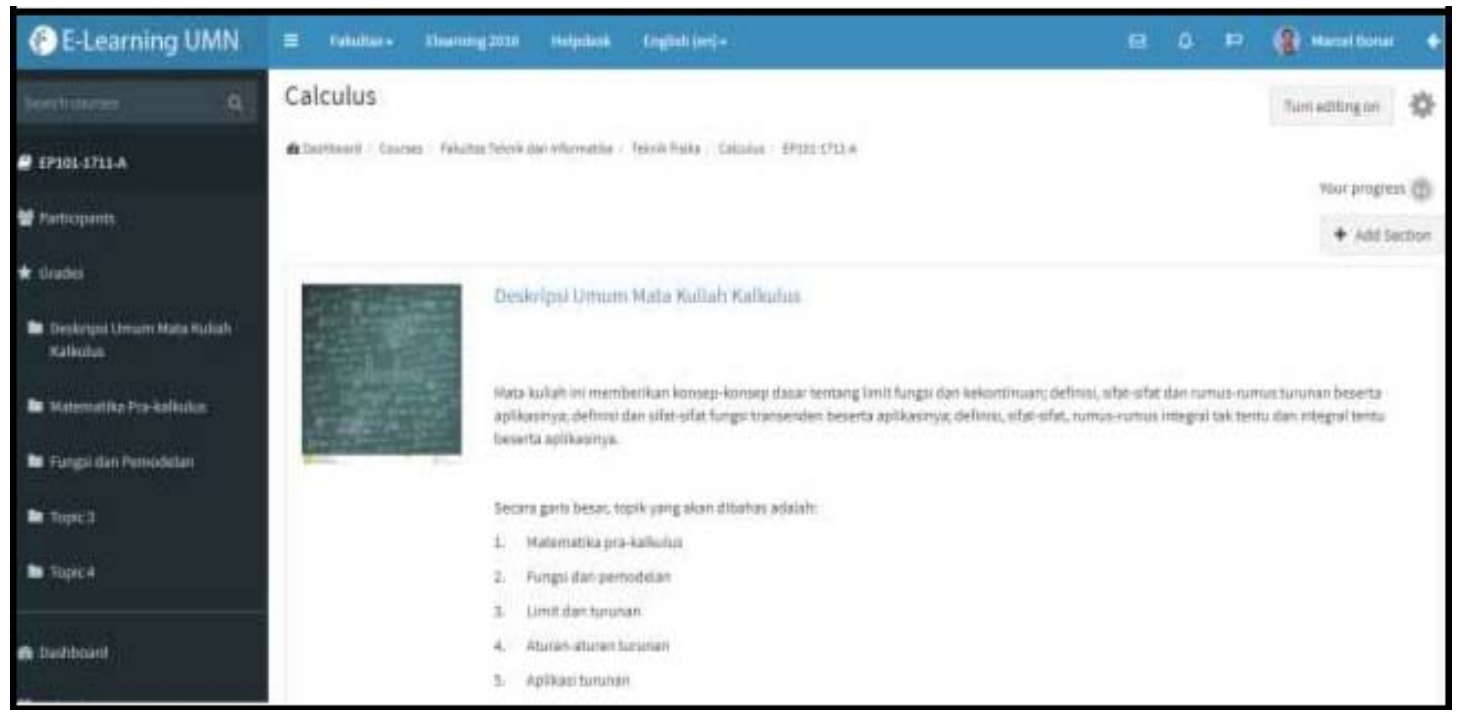


Figure 3. Screenshot of Online Test Sample

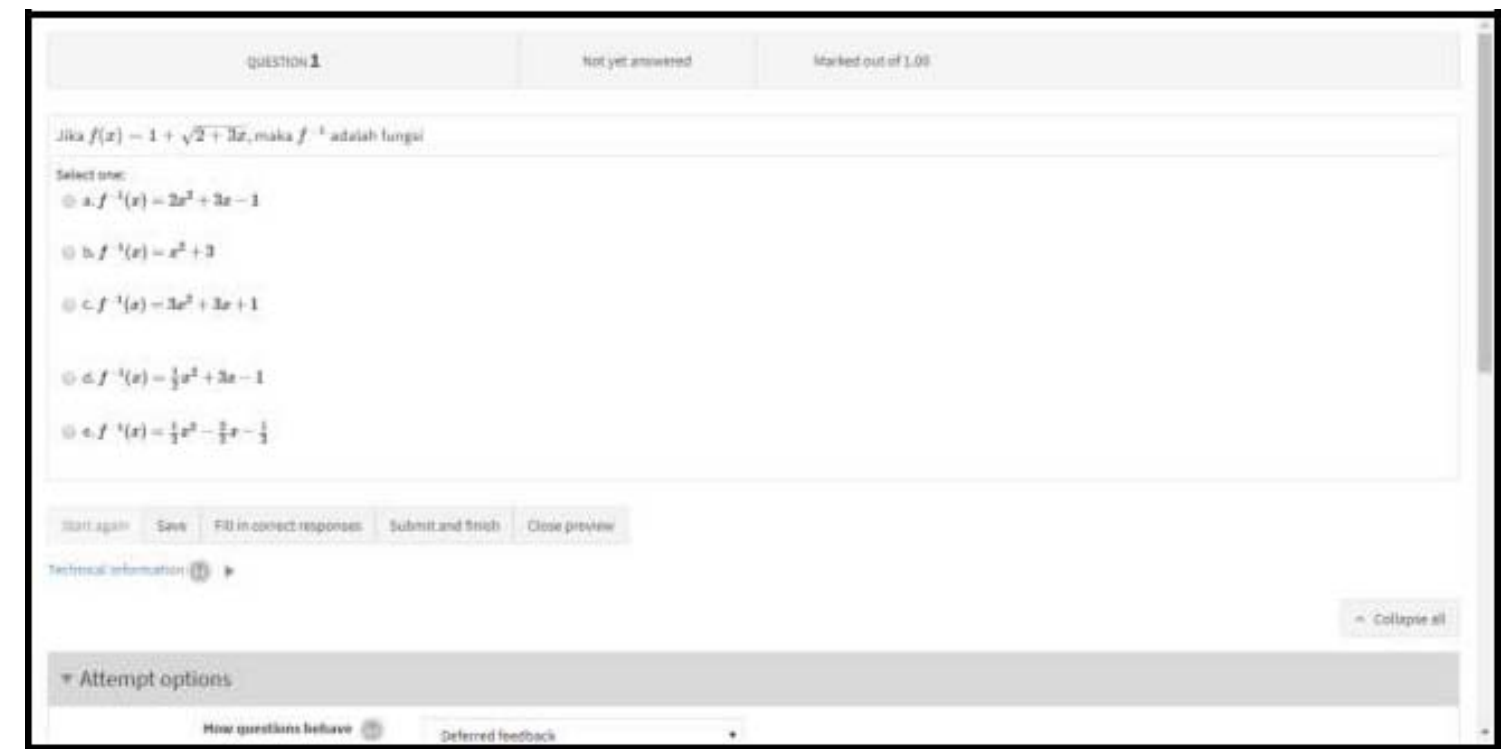




\section{RESULT AND DISCUSSION}

The total number of students who accessed online materials were 24 people enrolling in one class. Recapitulation of learning interaction for our blended learning method is given in Table 2.

Table 2. Learning Interaction Recapitulation

\begin{tabular}{|c|c|}
\hline Calculus & \\
\hline $\begin{array}{c}\text { Interactivity } \\
\text { type }\end{array}$ & Total Activity \\
\hline Resources & 8 \\
\hline Video & 7 \\
\hline Quiz & 5 \\
\hline Assignment & 2 \\
\hline Forum & 1 \\
\hline Online Class & 1 \\
\hline $\begin{array}{c}\text { Total } \\
\text { students }\end{array}$ & 24 \\
\hline
\end{tabular}

The definition for each of the Interactivity type is explained below. 
Resources are the posttest solution and explanation.

Video is a lesson activity consisting of several learning videos uploaded to third party servers and then embedded into UMN e-learning.

Quiz is an online pretest and posttest in the form of questions with multiple choice answers.

Assignment is posttest in the form of essay

Forum is a forum for group discussion

Online Class is an online synchronous mode meeting whose activity is listed on UMN elearning.

The online learning activities and face-to-face classrooms were held simultaneously. The level of student participation in each of online learning activity then monitored and can be seen in Table 3.

Table 3. Student Participation in online learning

\begin{tabular}{|c|c|c|c|c|c|}
\hline & & & $\begin{array}{l}\text { Calcu } \\
\text { us }\end{array}$ & & \\
\hline $\begin{array}{l}\text { Interacti } \\
\text { vity } \\
\text { type }\end{array}$ & $\begin{array}{l}\text { Tot } \\
\text { al } \\
\text { Acti } \\
\text { vity }\end{array}$ & $\begin{array}{l}\text { Total } \\
\text { Compl } \\
\text { etion }\end{array}$ & $\begin{array}{l}\text { Log } \\
\text { Repo } \\
\text { rt }\end{array}$ & $\begin{array}{l}\text { Perce } \\
\text { ntage } \\
\text { Compl } \\
\text { etion }\end{array}$ & $\begin{array}{l}\text { percent } \\
\text { age } \\
\text { log }\end{array}$ \\
\hline $\begin{array}{l}\text { Resour } \\
\text { ces }\end{array}$ & 8 & 0 & 63 & $0.00 \%$ & $32.81 \%$ \\
\hline Video & 7 & 42 & 65 & $\begin{array}{l}25.00 \\
\%\end{array}$ & $38.69 \%$ \\
\hline Quiz & 5 & 98 & 120 & $\begin{array}{l}81.67 \\
\%\end{array}$ & $\begin{array}{l}100.00 \\
\%\end{array}$ \\
\hline $\begin{array}{l}\text { Assign } \\
\text { ment }\end{array}$ & 2 & 22 & 48 & $\begin{array}{l}45.83 \\
\%\end{array}$ & $\begin{array}{l}100.00 \\
\%\end{array}$ \\
\hline Forum & 1 & 24 & 16 & $\begin{array}{l}100.0 \\
0 \%\end{array}$ & $66.67 \%$ \\
\hline
\end{tabular}




\begin{tabular}{|l|l|l|l|l|l|} 
& & & & & \\
\hline Online & 1 & 14 & 24 & 58.33 & 100.00 \\
Class & & & & \\
& & & & \\
\hline Total \\
student \\
s
\end{tabular}

As stated in the previous section, blended learning in the form of 7 asynchronous meeting was conducted before midterm exam. The students' grades on online tests and midterm exam are listed in Table 4.

Table 4. List of Students' Grades

\begin{tabular}{|c|c|c|c|c|c|c|c|c|c|}
\hline $\begin{array}{l}\text { First } \\
\text { name }\end{array}$ & Surname & $\begin{array}{l}\mathrm{Q} \\
\mathrm{u} \\
\mathrm{i} \\
\mathrm{z} \\
1\end{array}$ & $\begin{array}{l}\mathrm{Q} \\
\mathrm{u} \\
\mathrm{i} \\
\mathrm{z} \\
2\end{array}$ & $\begin{array}{l}\mathrm{A} \\
\mathrm{s} \\
\mathrm{s} \\
\mathrm{i} \\
\mathrm{g} \\
\mathrm{n} \\
1\end{array}$ & $\begin{array}{l}\mathrm{Q} \\
\mathrm{u} \\
\mathrm{i} \\
\mathrm{z} \\
3\end{array}$ & $\begin{array}{l}\text { A } \\
\text { s } \\
\text { s } \\
i \\
g \\
n \\
2\end{array}$ & $\begin{array}{l}\mathrm{Q} \\
\mathrm{u} \\
\mathrm{i} \\
\mathrm{z} \\
4\end{array}$ & $\begin{array}{l}\text { Q } \\
\text { u } \\
\mathrm{i} \\
\mathrm{z} \\
5\end{array}$ & $\begin{array}{l}M \\
i \\
d \\
\text {. }\end{array}$ \\
\hline STEVEN & & $\begin{array}{l}1 \\
0 \\
0\end{array}$ & $\begin{array}{l}9 \\
0\end{array}$ & $\begin{array}{l}5 \\
0\end{array}$ & $\begin{array}{l}1 \\
0 \\
0\end{array}$ & $\begin{array}{l}8 \\
0\end{array}$ & $\begin{array}{l}7 \\
5\end{array}$ & $\begin{array}{l}3 \\
7 \\
5 \\
5\end{array}$ & $\begin{array}{l}7 \\
9\end{array}$ \\
\hline
\end{tabular}




\begin{tabular}{|c|c|c|c|c|c|c|c|c|c|}
\hline $\begin{array}{l}\text { CHRIST } \\
\text { OPHER } \\
\text { LEONAR } \\
\text { D }\end{array}$ & & $\begin{array}{l}1 \\
0 \\
0\end{array}$ & $\begin{array}{l}9 \\
0\end{array}$ & $\begin{array}{l}8 \\
0\end{array}$ & $\begin{array}{l}1 \\
0 \\
0\end{array}$ & $\begin{array}{l}8 \\
5\end{array}$ & $\begin{array}{l}7 \\
5\end{array}$ & $\begin{array}{l}7 \\
5\end{array}$ & $\begin{array}{l}9 \\
9\end{array}$ \\
\hline $\begin{array}{l}\text { CAROLI } \\
\text { NE }\end{array}$ & & $\begin{array}{l}1 \\
0 \\
0\end{array}$ & $\begin{array}{l}9 \\
0\end{array}$ & $\begin{array}{l}9 \\
0\end{array}$ & $\begin{array}{l}1 \\
0 \\
0\end{array}$ & $\begin{array}{l}8 \\
5\end{array}$ & $\begin{array}{l}6 \\
2 \\
5\end{array}$ & $\begin{array}{l}6 \\
2 \\
5\end{array}$ & $\begin{array}{l}9 \\
3\end{array}$ \\
\hline $\begin{array}{l}\text { EMILIO } \\
\text { YUDHAT } \\
\text { AMA }\end{array}$ & & $\begin{array}{l}9 \\
0\end{array}$ & $\begin{array}{l}9 \\
0\end{array}$ & $\begin{array}{l}6 \\
0\end{array}$ & $\begin{array}{l}1 \\
0 \\
0\end{array}$ & $\begin{array}{l}8 \\
0\end{array}$ & $\begin{array}{l}3 \\
7 \\
5\end{array}$ & $\begin{array}{l}1 \\
0 \\
0\end{array}$ & $\begin{array}{l}7 \\
2\end{array}$ \\
\hline $\begin{array}{l}\text { RIEFQI } \\
\text { RAMAD } \\
\text { HIKA }\end{array}$ & & $\begin{array}{l}8 \\
0\end{array}$ & $\begin{array}{l}9 \\
0\end{array}$ & - & $\begin{array}{l}9 \\
0\end{array}$ & $\begin{array}{l}7 \\
0\end{array}$ & $\begin{array}{l}3 \\
7 \\
5 \\
5\end{array}$ & $\begin{array}{l}7 \\
5\end{array}$ & $\begin{array}{l}3 \\
0\end{array}$ \\
\hline $\begin{array}{l}\text { ADHIST } \\
\text { ANA }\end{array}$ & $\begin{array}{l}\text { ADHIPRADA } \\
\text { NA }\end{array}$ & $\begin{array}{l}8 \\
0\end{array}$ & $\begin{array}{l}7 \\
0\end{array}$ & $\begin{array}{l}6 \\
0\end{array}$ & $\begin{array}{l}2 \\
0\end{array}$ & $\begin{array}{l}7 \\
5\end{array}$ & - & $\begin{array}{l}2 \\
5\end{array}$ & $\begin{array}{l}3 \\
0\end{array}$ \\
\hline $\begin{array}{l}\text { PUTU } \\
\text { GANDHI }\end{array}$ & $\begin{array}{l}\text { ADITYA } \\
\text { BAYUNTAR } \\
\text { A }\end{array}$ & $\begin{array}{l}9 \\
0\end{array}$ & $\begin{array}{l}8 \\
0\end{array}$ & $\begin{array}{l}8 \\
0\end{array}$ & $\begin{array}{l}8 \\
0\end{array}$ & $\begin{array}{l}7 \\
5\end{array}$ & $\begin{array}{l}6 \\
2 \\
5 \\
5\end{array}$ & $\begin{array}{l}2 \\
5\end{array}$ & $\begin{array}{l}5 \\
2\end{array}$ \\
\hline REZA & $\begin{array}{l}\text { AFRIANI } \\
\text { MAULANA }\end{array}$ & $\begin{array}{l}8 \\
0\end{array}$ & $\begin{array}{l}8 \\
0\end{array}$ & $\begin{array}{l}7 \\
0\end{array}$ & $\begin{array}{l}9 \\
0\end{array}$ & $\begin{array}{l}8 \\
0\end{array}$ & $\begin{array}{l}2 \\
5\end{array}$ & $\begin{array}{l}7 \\
5\end{array}$ & $\begin{array}{l}3 \\
0\end{array}$ \\
\hline
\end{tabular}




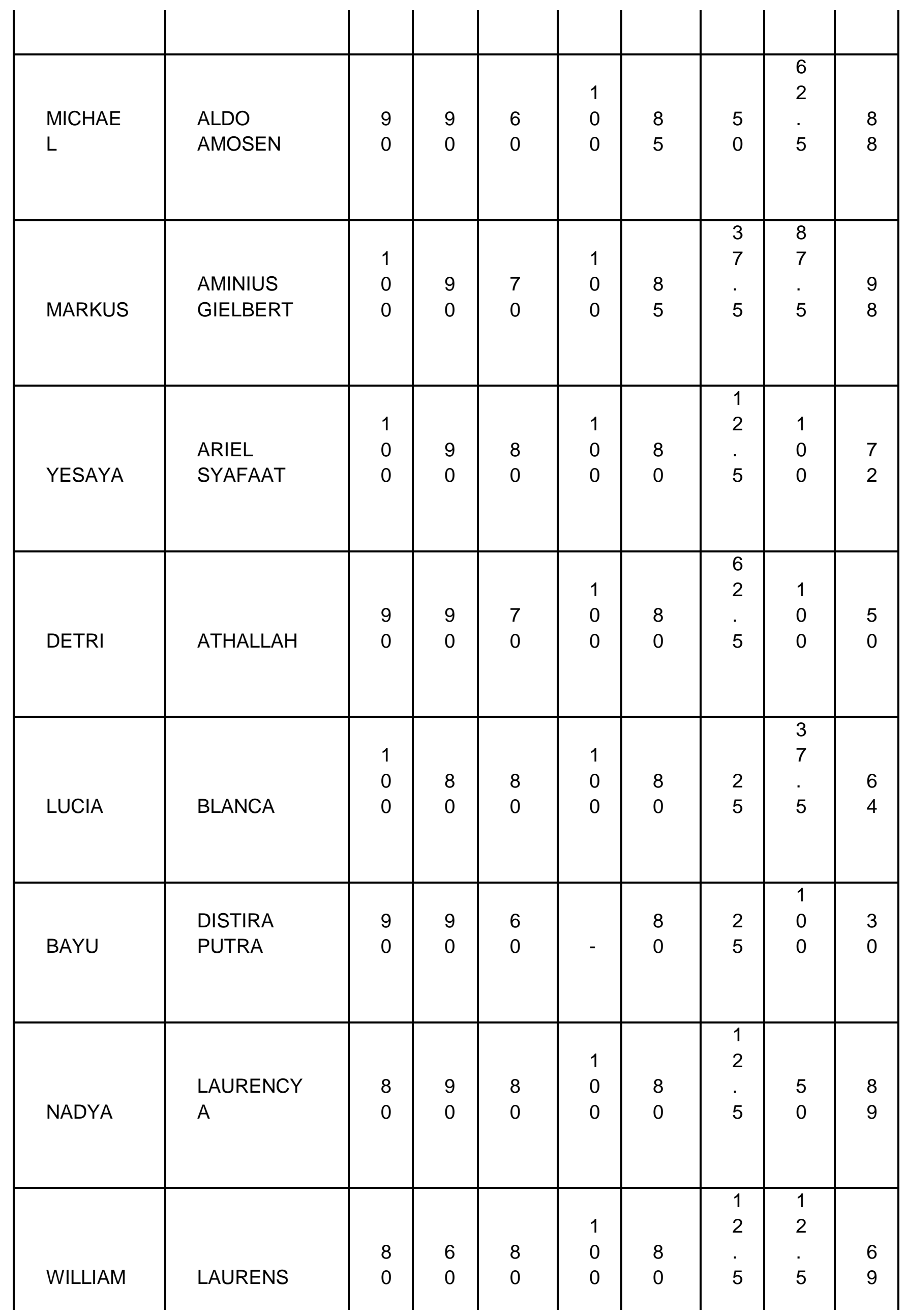




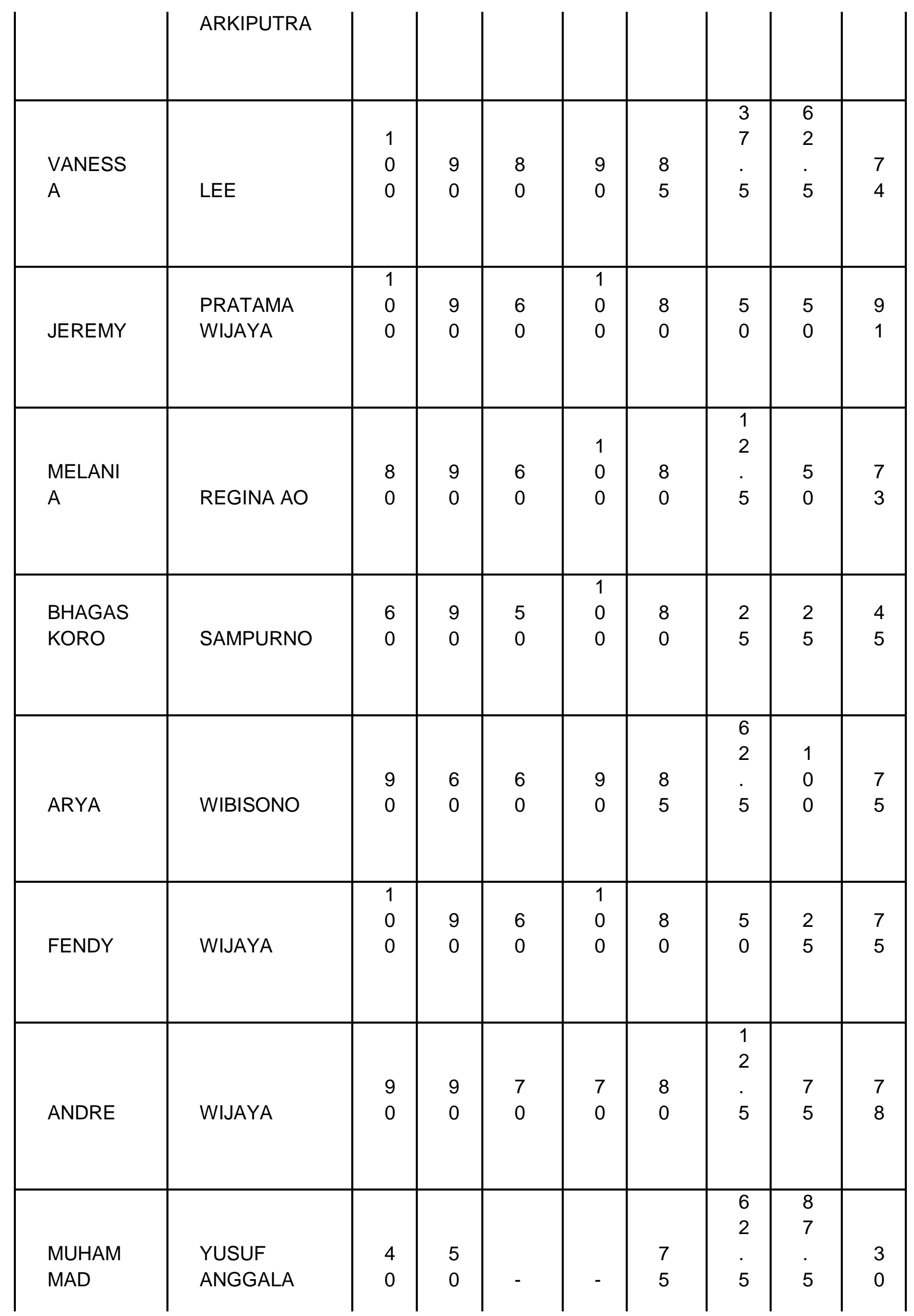




\begin{tabular}{|l|l|l|l|l|l|l|l|l|} 
SIAGIAN & & & & & & & & \\
\hline
\end{tabular}

As can be seen from Table 4, the average midterm exam grade was 66.08. This is considerably higher than the average of previous year's class, 51.82. Furthermore, it can be observed that most students with higher online test scores also got better midterm exam marks. It shows that the students who studied calculus with blended learning method received an overall more effective learning experience. Although the success rate of passing calculus is influenced by the motivation of the students to work on the online activities that have been prepared by the lecturer. It is found that the combination of in-person classroom time and selfstudying with on-line activities are a good method to learn calculus.

Despite the positive findings in Table 4, Table 3 shows that not all online materials are fully utilized by the students. In particular, only a quarter of the students watched the online videos completely. Two potential remedies for this are (i) setting the activity itself a part of final grades, (ii) producing more interesting learning video contents. These two factors will be studied further in future studies.

\section{CONCLUSION AND SUGGESTION}

Blended learning was applied by combining the advantages of traditional in class teaching method with online learning to make the learning process more effective and efficient. The online content developed in this project were in the form of short videos and question banks as well as the solutions for student's exercises. The result shows that the students studied calculus with blended learning method passed with higher passing grade compared with conventional teaching in class method. Furthermore, it also indicates that the success rate of passing calculus is influenced by the motivation of the students to work on the online activities that have been prepared by the lecturer. The combination of in-person classroom time and selfstudying with on-line activities are a good method to learn and understanding calculus.

\section{ACKNOWLEDGEMENTS}

The authors acknowledge financial support from Direktorat Pembelajaran, Direktorat Jenderal Pembelajaran dan Kemahasiswaan, Kementerian Riset, Teknologi dan Pendidikan Tinggi (Hibah SPADA 2017) and also Universitas Multimedia Nusantara. 


\section{REFERENCES}

Asarta, C.J. \& Schmidt, J.R. (2016), Comparing student performance in blended and traditional courses: Does prior academic achievement matter?, The Internet and Higher Education, doi: 10.1016/j.iheduc.2016.08.002

Alhabeeb A. \& Rowley J.(2018), E-learning critical success factors: Comparing perspectives

from academic staff and students, Computers \& Education, doi: 10.1016/ j.compedu.2018.08.007.

Etem Yesilyurt, Abdulhak Hali Ulas, Durdagi Akan (2016), Teacher self-efficacy, academic self-efficacy, and computer self-efficacy as predictors of attitude towards applying computer-supported education, Computer in Human Behavior, 64, 591-601.

Hamidreza Kashefia, Zaleha Ismail, Yudariah Mohammad Yusof (2012), Overcoming Students Obstacles in Multivariable Calculus through Blended Learning: A Mathematical Thinking Approach, Procedia - Social and Behavioral Sciences, $56,579-586$.

Ilona Semradova \& Sarka Hubackova ( 2016 ), Teacher responsibility in distance education, Procedia - Social and Behavioral Sciences, 217, 544 - 55

Maria de Fátima Goulão, Rebeca Cerezo Menedez (2015), Learner autonomy and self-regulation in eLearning, Procedia - Social and Behavioral Sciences, 174, $1900-1907$

Marta Graciela Caligaris, María Elena Schivo, María Rosa Romit (2015), Calculus \& GeoGebra, an interesting partnership, Procedia - Social and Behavioral Sciences, 174, 1183

M.R. Estela Carbonell, J. Saà-Seoane, J. Villalonga Pons (2012), Innovative selfassessment and teaching/learning techniques for Calculus within the RIMA project (UPC-ICE), Procedia - Social and Behavioral Sciences, 46, 686 - 691

Rohani Ahmad Tarmizi (2010), Visualizing Students' Difficulties in Learning Calculus, International Conference on Mathematics Education Research 2010 (ICMER 2010)

Rostaminezhad, M.A, Mozayani, N, Norozi, D, Iziy, M (2013), Related to E-learner Dropout: Case Study of IUST Elearning Center Procedia - Social and Behavioral Sciences, 83, $522-527$ 
Rohani Ahmad Tarmizi (2010), Visualizing Students' Difficulties in Learning Calculus, Social and Behavioral Sciences, 8, 377-383

Sarka Hubackova, llona Semradova ( 2016 ), Evaluation of Blended Learning, Procedia - Social and Behavioral Sciences, 217, 551 - 557.

Tuan Salwani Awang @ Salleh, Effandi Zakaria (2013), Enhancing Students' Understanding in Integral Calculus through the Integration of Maple in Learning, Procedia - Social and Behavioral Sciences, 102, $204-211$

Veselin Jungic, Deborah Kent and Petra Menz (2012), On Online Assignments in a Calculus Class, Journal of University Teaching \& Learning Practice, 9(1), Available at:http://ro.uow.edu.au/jutlp/vol9/iss1/3

Yao Lin.C. (2008), Beliefs about using technology in mathematics classroom: Interview with pre-service elementary teachers. Eurasia Journal of Mathematics, Science\&Technology education, 4(2), 135-142.

\section{ABOUT THE AUTHORS}

Hira Meidia: Vice Rector for Academic Affairs / Senior Lecturer ar Electrical Engineering Department, Universitas Multimedia Nusantara, Jl. Raya Boulevard, Sumarecon, Serpong, Tangerang 15810, Indonesia

Caesar O Harahap, Senior Lecturer at Physics Engineering Department, Universitas Multimedia Nusantara, Jl. Raya Boulevard, Sumarecon, Serpong, Tangerang 15810, Indonesia

Nabila H Shabrina, Lecturer at Computer Engineering Department, Universitas Multimedia Nusantara, Jl. Raya Boulevard, Sumarecon, Serpong, Tangerang 15810, Indonesia

Marcel Bonar, Manager Online Learning Development/ Lecturer at Informatics Department, Universitas Multimedia Nusantara, Jl. Raya Boulevard, Sumarecon, Serpong, Tangerang 15810, Indonesia 